\title{
POLA PENGASUHAN ALTERNATIVE DUAL CAREER FAMILY DALAM PEMENUHAN KEBUTUHAN ASIH ANAK
}

Tawaduddin Nawafilaty ${ }^{\text {a. } 1}$

${ }^{a}$ Universitas Islam Lamongan Indonesia

1 dina.filaty@gmail.com

\begin{tabular}{l}
\hline Informasi artikel \\
\hline Received : \\
Feb 15, 2019. \\
Revised : \\
Feb 27, 2019. \\
Publish : \\
Maret 09, 2019. \\
Kata kunci: \\
Pengasuhan \\
Alternatif; \\
Dual-Career Family; \\
Anak-Anak; \\
\end{tabular}

Keywords:

Alternative Parenting; Dual-Career Family; children;

\begin{abstract}
ABSTRAK
Kajian tentang pencarian bentuk pengasuhan alternatif pun banyak dilakukan seiring semakin lazimnya fenomena dual-career family. Dualcareer family sendiri menunjuk pada fenomena keluarga dimana ayah dan ibu sama-sama bekerja di luar rumah sehingga harus menggandeng pihak lain untuk berjasama dalam mengasuh anak. Boleh jadi pihak lain tersebut adalah kepada kakek-nenek dari si anak, paman-bibi, tetangga, asisten rumah tangga, atau taman penitipan anak (day care). Penelitian ini bertujuan untuk memperoleh gambaran tentang model pengasuhan alternatif pada keluarga dual-career, peneliti membatasi penelitiannya pada subjek dengan kriteria dual-career yang mempunyai anak usia 0-8 tahun, atau yang dikenal dengan anak usia dini. Pengasuhan yang dimaksud menunjuk pada cara tertentu yang dilakukan oleh orangtua dalam memenuhi kebutuhan dasar seorang anak, yaitu kebutuhan asih. Hasil penelitian ini diharapkan dapat menjadi tambahan warna dalam konstruk teori pola asuh anak sesuai dengan karakteristik dual-career family.

\section{ABSTRACT}

Studies on the search for alternative forms of care are also carried out in line with the increasingly prevalent phenomenon of dual-career family. Dual-career family itself refers to the family phenomenon where fathers and mothers both work outside the home so they must hold other parties to work together in parenting. The other party may be to the child's grandparents, uncles, neighbors, household assistants, or day care parks. This study aims to obtain an overview of alternative care models for dualcareer families, researchers limit their research to subjects with dualcareer criteria who have children aged 0-8 years, or known as early childhood. Parenting referred to refers to a certain way that is done by parents in meeting a child's basic needs, namely the needs of caring. The results of this study are expected to be an additional color in the construct of child care theory in accordance with the characteristics of a dualcareer family.
\end{abstract}

This work is licensed under a Creative Commons Attribution-ShareAlike 4.0 International License. Allows readers to read, download, copy, distribute, print, search, or link to the full texts of its articles and allow readers to use them for any other lawful purpose. 


\section{PENDAHULUAN}

Keluarga merupakan suatu sistem yang kompleks dimana di dalamnya terdapat ikatan diantra anggota keluarganya dan saling memiliki. Di lingkungan keluarga inilah terjadi proses pengasuhan demi terbentuknya pribadi yang matang untuk dapat menjalani kehidupan sesuai yang diharapkan. Salah satu sosok yang paling berperan dalam pembentukan kepribadian tersebut tentunya adalah orang tua. Orang tua menjadi pendamping utama dalam setiap perkembangan anak. Orang tua menjadi contoh pertama dan yang paling utama bagi anak. Orang tua melakukan "investasi dan komitmen dalam kehidupan anak" untuk memberikan tanggung jawab dan perhatian (Brooks, 2008:23).

Pengertian keluarga berarti nuclear family yaitu yang terdiri dari ayah, ibu dan anak. Ayah dan ibu dalam melaksanakan tanggung jawab sebagai orang tua dan mampu memenuhi tugas sebagai pendidik. Oleh karena itu keluarga mempunyai peranan yang besar dalam mempengaruhi kehidupan seorang anak, terutama pada tahap awal maupun pada tahap-tahap kritisnya dan yang paling berperan sebagai pendidik anak-anaknya adalah ibu. Peran seorang ibu dalam keluarga terutama anak adalah pendidik dan menjaga anak-anaknya dari usia bayi hingga dewasa, karena anak tidak jauh dari pengamatan orangtua terutama ibunya.

Pada jaman modern ini, fenomena tentang ibu bekerja di daerah perkotaan di anggap sudah tidak asing lagi. Ketika pada jaman dahulu seorang istri hanya berperan sebagai pengurus rumah dan anak/suami, seiring berjalannya waktu dan kemajuan ilmu pengetahuan bahkan seorang ibu dapat menjalankan peran ganda. Bagi yang mengalami, mungkin karena tuntutan hidup atau keinginan untuk tetap bergelut di 
dunia karir namun seorang ibu ditutut untuk mampu menaggung peran ganda tersebut yaitu menjadi seorang ibu rumah tangga yang berkewajiban untuk mengurus perihal rumah tangga serta memenuhi kebutuhan keluarga melalui kegiatan berkarir didunia kerja. Seorang ibu tersebut tentunya membutuhkan banyak waktu untuk sekedar bersama anak. Sehingga proses pengasuhan tetap berjalan secara maksimal. Seorang profesor sosiologi dan studi wanita di Universitas Wellesley mengungkapkan fakta mengenai masyarakat yang membebaskan wanita untuk memilih menjadi ibu atau berkarir. Alih-alih menjadi ibu yang mengasuh anak, wanita karir banyak yang beranggapan bahwa mempunyai anak akan tidak efektif karena waktu yang tidak benar-benar cukup untuk anak (Hertz, 2008:35). Beberapa wanita yang berperan ganda menempatkan anak-anak ditempat penitipan atau menyewa pengasuh utama bagi anak. Seorang wanita tidak hanya sukses karir namun setidaknya dimata orang lain gagal dalam membangun rumah tangga karena tidak memiliki anak. Hal inilah yang membuat proses pengasuhan ibu bekerja tidak dapat dikatakan "mudah" Namun tentu seorang ibu sudah memiliki pertimbangan khusus dalam menjalankan peran ganda mereka.

Ibu bekerja adalah ibu yang melakukan suatu kegiatan di luar rumah dengan tujuan untuk mencari nafkah untuk keluarga. Selain itu salah satu tujuan ibu bekerja adalah suatu bentuk aktualisasi diri guna menerapkan ilmu yang telah dimiliki ibu dan menjalin hubungan sosial dengan orang lain dalam bidang pekerjaan yang dipilihnya (Santrock, 2002:157). Beberapa alasan yang mendukung tujuan ibu bekerja menurut adalah:

1. Karena keharusan ekonomi, untuk meningkatkan ekonomi keluarga. Hal ini terjadi karena ekonomi keluarga yang menuntut ibu untuk bekerja. Misalnya saja bila 
kehidupan ekonomi keluarganya kurang, penghasilan suami kurang untuk mencukupi kebutuhan sehari - hari keluarga sehingga ibu harus bekerja,

2. Karena ingin mempunyai atau membina pekerjaan. Hal ini terjadi sebagai wujud aktualisasi diri ibu, misalnya bila ibu seorang sarjana akan lebih memilih bekerja untuk membina pekerjaan,

3. Proses untuk mengembangkan hubungan sosial yang lebih luas dengan orang lain dan menambah pengalaman hidup dalam lingkungan pekerjaan,

4. Karena kesadaran bahwa pembangunan memerlukan tenaga kerja baik tenaga kerja pria maupun wanita. Hal ini terjadi karena ibu mempunyai kesadaran nasional yang tinggi bahwa negaranya memerlukan tenaga kerja demi melancarkan pembangunan,

5. Pihak orang tua dari ibu yang menginginkan ibu untuk bekerja,

6. Karena ingin memiliki kebebasan finansial, dengan alasan tidak harus bergantung sepenuhnya pada suami untuk memenuhi kebutuhan sendiri, misalnya membantu keluarga tanpa harus meminta dari suami,

7. Bekerja merupakan suatu bentuk penghargaan bagi ibu,

8. Bekerja dapat menambah wawasan, yang pada akhirnya akan meningkatkan kualitas pola asuh anak-anak.

Alasan-alasan di atas menjadi dasar terjadinya pergeseran nilai peran seorang ibu. Ibu harus menjalankan peran ganda dalam melaksanakan perannya sebagai sosok seorang ibu. Peran ganda ini berpengaruh positif maupun negatif terhadap kondisi keluarga terutama terhadap anak. Pengaruh ibu yang bekerja pada hubungan anak dan ibu, sebagian besar bergantung pada usia anak pada waktu ibu mulai bekerja. Jika ibu mulai bekerja sebelum anak telah terbiasa selalu bersamanya, yaitu sebelum suatu 
hubungan tertentu terbentuk, maka pengaruhnya akan minimal. Tetapi jika hubungan yang baik telah terbentuk, anak itu akan menderita akibat deprivasi maternal, kecuali jika seorang pengganti ibu yang memuaskan tersedia, yaitu seorang pengganti yang disukai anak dan yang mendidik anak dengan cara yang tidak akan menyebabkan kebingungan atau kemarahan di pihak anak (Hurlock, 2007:198).

Secara umum, teori bioekologi menyebutkan bahwa perkembangan manusia sepanjang hayat dipengaruhi oleh empat lingkungan dimana ia hidup, yang mana keempat lingkungan tersebut disebut dengan kronosistem (chronosystem). Keempat lingkungan dalam kronosistem tersebut adalah: mikrosistem (microsystem), mesosistem (mesosystem), eksosistem (exosystem), dan makrosistem (macrosystem). Mikrosistem mencakup: keluarga, sekolah, tempat penitipan anak, tetangga dan lingkungan tempat tinggal, media massa yang beredar di sekitar, serta teman sebaya atau teman bermain sehari-hari.Mesosistem mencakup: hubungan keluarga dengan tetangga sekitar, kebiasaan teman bermain dalam memilih jenis tontonan TV di media massa, nilai-nilai yang dikembangkan di sekolah atau penitipan anak, dll. Mesosistem ini merupakan hubungan antar unsur yang ada dalam mikrosistem. Eksosistem mencakup: pekerjaan orangtua, kebijakan sekolah yang berasal dari pemerintah, kondisi perekonomian kota, dll. Eksosistem tidak berpengaruh secara langsung kepada anak akan tetapi dapat dirasakan dampaknya dalam perkembangan anak. Makrosistem mencakup: kondisi negara, agama, perkembangan teknologi, ideologi politik, budaya bangsa, dll. yang lebih luas cakupannya. Dalam cincin lingkar pertama lah keluarga menjadi pihak terdekat dan terpenting dalam pembentukan karakter tumbuhkembangnya. Jika keluarga mampu menjalankan peran dan fungsinya secara optimal, 
anak akan tumbuh dan berkembang pula secara optimal menyelesaikan tugas-tugas perkembangannya.

Dilihat dari keadaan dilapangan yang dimana pola pengasuhan dual-career family dengan posisi ibu bekerja di universitas dan rata-rata mereka bekerja dalam waktu 8 jam perhari, begitupula dengan tuntutan tridarma perguruan tinggi untuk melakukan pengajaran, penelitian dan pengabdian yang sekiranya membutuhkan banyak waktu untuk berada dikantor dan diluar ruangan sehingga anak-anak lebih banyak menghabiskan waktu dengan kakek-nenek dan pengasuhnya begitupun ditunjang dengan kajian yang dilakukan oleh UNICEF Indonesia tentang Perlindungan Anak menemukan fakta bahwa "tidak adanya model pengasuhan alternatif merupakan hambatan utama untuk mengubah paradigma dari fokus pada pengasuhan di institusi. Anak-anak tanpa pengasuhan orang tua dan anak-anak dari keluarga miskin memerlukan pilihan-pilihan lain selain tinggal di lembaga pengasuhan anak untuk dapat tumbuh dalam lingkungan yang melindungi dan untuk melanjutkan pendidikan mereka. Opsi pengasuhan berbasis keluarga perlu dikembangkan dalam sistem pengasuhan alternatif yang didukung dan diatur oleh pemerintah". (UNICEF Indonesia, 2012). Fakta tersebut menggugah pemerhati Psikologi pendidikan dan perkembangan anak untuk menemukan pola pengasuhan yang cukup adekuat dalam pengasuhan alternatif pengganti pengasuhan orangtua. Penelitian ini, dengan tujuan tersebut mencoba menemukan model pengasuhan alternatif pada keluarga dengan kedua orangtua yang bekerja. Mengkajinya dari sudut pandang Psikologi pendidikan dan perkembangan anak, dengan analisis berbasis teori Bioekologi Urie Bronfenbrenner tentang pengaruh lingkungan dalam tumbuh-kembang. 
Tujuan penelitian ini untuk memberikan kontribusi pola pengasuhan anak dimana ayah dan ibu sama-sama bekerja (dual-career family).

\section{METODOLOGI}

Sumber data penelitian studi kasus dapat diperoleh dari semua pihak yang bersangkutan, dengan kata lain data dalam studi ini dikumpulkan dari berbagai sumber. Sebagai sebuah studi kasus maka data yang dikumpulkan berasal dari berbagai sumber dan hasil penelitian ini hanya berlaku pada kasus yang diselidiki. Lebih lanjut Arikunto (1986) mengemukakan bahwa metode studi kasus sebagai salah satu jenis pendekatan deskriptif, adalah penelitian yang dilakukan secara intensif, terperinci dan mendalam terhadap suatu organisme (individu), lembaga atau gejala tertentu dengan daerah atau subjek yang sempit. Dalam penelitian ini adalah laporan hasil wawancara dan observasi yang dilakukan terhadap subjek penelitian, yaitu pasangan orangtua dual-careerdengan criteria yang telah ditetapkan sebagai berikut:

1. Pasangan suami-istri yang masing-masing menekuni bidang pekerjaan atau bekerja di luar rumah selama minimal 3 jam dalam sehari, 2 hari dalam seminggu.

2. Pasangan suami istri yang istri bekerja di universitas di wilayah Kabupaten Lamongan

3. Pasangan suami-istri yang mempunyai anak biologis usia 0-8 tahun.

4. Pasangan suami-istri yang melimpahkan tanggungjawab pengasuhan anak kepada pihak ketiga, baik pihak ketiga itu adalah orangtua (nenek bagi si anak), kerabat, maupun pihak yang secara khusus ditunjuk atau dilimpahi pengasuhan anak, misalnya pembantu rumah tangga, pengasuh anak (baby sitter), atau pengasuh TPA bagi anak yang dititipkan pada tempat penitipan anak. 
5. Pasangan-suami istri yang tinggal di wilayah Kabupaten Lamongan Jawa Timur.

Penelitian ini menggunakan teknik pengumpulan data melalui wawancara, observasi, serta Focused Group Discussion (FGD).

1. Wawancara.

Wawancara merupakan proses interaksi atau komunikasi secara langsung antara pewawancara dengan informan. Dengan wawancara, data yang dikumpulkan dapat bersifat; 1) Fakta, misalnya umur, pendidikan, pekerjaan, dll; 2) Sikap, misalnya sikap terhadap kebutuhan kasih sayang seorang anak, sikap terhadap peran pengasuh, dll.; 3) Pendapat, misalnya pendapat tentang status pekerjaan orangtua dan pengaruhnya terhadap tumbuh kembang anak; 4) Keinginan, misalnya kondisi anak yang diinginkan, gaji yang diharapkan, dll; 5) Pengalaman, misalnya pengalaman mengasuh anak sebelum bekerja, pengalaman mencari pembantu pengasuh anak, dll.

\section{Observasi.}

Hasil observasi berupa aktivitas, kejadian, peristiwa, objek, kondisi atau suasana tertentu, dan perasaan emosi seseorang. Observasi dilakukan untuk memperoleh gambaran riil suatu peristiwa atau kejadian untuk menjawab pertanyaan penelitian. Observasi terdiri dari beberapa bentuk, yaitu: 1). Observasi partisipasi (participant observation) adalah metode pengumpulan data yang digunakan untuk menghimpun data penelitian melalui pengamatan dan penginderaan di mana peneliti terlibat dalam keseharian informan, 2). Observasi tidak terstruktur ialah pengamatan yang dilakukan tanpa menggunakan pedoman observasi, sehingga peneliti mengembangkan pengamatannya berdasarkan perkembangan yang terjadi di lapangan, dan 3). Observasi kelompok ialah pengamatan yang dilakukan oleh sekelompok tim peneliti terhadap sebuah isu yang diangkat menjadi objek penelitian. 
Dalam penelitian ini, yang digunakan adalah observasi partisipasi dan observasi terstruktur.

\section{Focus Group Discussion (FGD).}

Focus Group Discussion (FGD) adalah teknik pengumpulan data yang umumnya dilakukan pada penelitian kualitatif dengan tujuan menemukan makna sebuah tema menurut pemahaman sebuah kelompok. Teknik ini digunakan untuk mengungkap pemaknaan dari suatu kelompok berdasarkan hasil diskusi yang terpusat pada suatu permasalahan tertentu.

\section{HASIL DAN PEMBAHASAN}

\section{Hasil Penelitian}

Data hasil penelitian diperoleh dari hasil observasi berupa aktivitas, kejadian, peristiwa, objek, kondisi atau suasana tertentu, dan perasaan emosi seseorang. Observasi partisipasi (participant observation) dan observasi tersetruktur dimana peneliti mengumpulkan data yang digunakan untuk menghimpun data penelitian melalui pengamatan dan penginderaan di mana peneliti terlibat dalam keseharian informan dengan terjun langsung kelapangan mengamati dan mengelompokan subyek penelitian dari hasil observasi tersebut peneliti memperoleh data dari enam informan yang akan peneiti wawancarai.

Wawancara dilakukan terhadap enam informan yang dianggap represtatf terhadap obyek masalah dalam penelitian. Berikut ini merupakan data dari enam informan dalam penelitian ini.

a. Keluarga I dengan pekerjaan sebagai dosen di, dan suami bekerja sebagai PNS serta mempunyai anak yang berusia enambelas bulan pada saat mereka bekerja anak diasuh oleh Oma, 
b. Keluarga II dengan pekerjaan sebagai dosen dan suami bekerja sebagai wiraswasta serta mempunyai anak yang berusia enam bulan, pada saat mereka bekerja anak diasuh oleh asisten rumah tangga,

c. Keluarga III dengan pekerjaan sebagai dosen dan suami bekerja sebagai perawat serta mempunyai anak yang tigabelas bulan, pada saat mereka bekerja anak diasuh oleh neneknya,

d. Keluarga IV dengan pekerjaan sebagai dosen dan suami bekerja sebagai karyawan swasta serta mempunyai anak yang delapan bulan, pada saat mereka bekerja anak diasuh oleh tetangga,

e. Keluarga V dengan pekerjaan sebagai dosen dan suami bekerja sebagai guru serta mempunyai anak yang enambelas bulan, pada saat mereka bekerja anak diasuh oleh asisten rumah tangga,

f. Keluarga IV dengan pekerjaan sebagai dosen di Universitas Islam Lamongan, dan suami bekerja sebagai karyawan swasta serta mempunyai anak yang sembilanbelas bulan, pada saat mereka bekerja anak diasuh oleh ibu merutua atau ibu dari suami

Data yang diperoleh dari wawancara berupa jawaban informan atas pertanyaan yang diajukan oleh penelitian melalui panduan wawancara yang dilakukan secara tatap muka langsung dengan informan, yang kemudian data jawaban tersebut disajikan dalam bentuk kutipan hasil wawancara. Kutipan hasil wawancara tersebut memaparkan jawaban responden yang beragam mengenai model pengasuhan alternatif dual-career family dalam pemenuhan kebutuhan asih anak. Guna menjawab rumusan masalah. Kutipan hasil wawancara dari informan penelitian tersebut secara lebih rinci diuraikan serta dijelaskan berikut ini: 


\section{Keluarga I: Ayah PNS, Ibu Dosen}

Motivasi dual-career : Untuk menjamin masa depan anak.

Pihak kedua: Nenek

Pemahaman tentang golden age: Memahami bahwa usia dimana otak anak mampu secara cepat menyerap berbagai informasi yang diterima dari lingkungan.

Model pemenuhan asih: Memberikan full waktu untuk anak ketika dirumah dan mengajaknya quality time ketika libur kerja.

\section{Keluarga II: Ayah Wiraswasta, Ibu Dosen}

Motivasi dual-career: Memahami bahwa bekerja adalah suatu ibadah dan juga untuk memenuhi keutuhan sehari-hari

Pihak kedua: Asisten Rumah tangga dan Ayah

Model pemenuhan asih: Selalu memberikan kasih sayang dan pujian saat anak dapat melakukan perkembangan-perkembangan pada tahap usinya.

\section{Keluarga III: Ayah Perawat, Ibu Dosen}

Motivasi dual-career: Tuntutan hidup untuk memenuhi kebutuhan sehari-hari.

Pihak kedua: Nenek

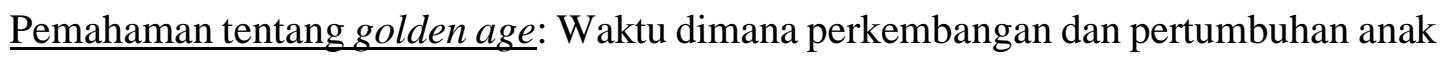
berkembang begitu pesat.

Model pemenuhan asih: Memberikan perhatian, kasih sayang, mengajarkan tanggungjawab, kemandirian dan rasa aman serta nyaman bagi anak.

\section{Keluarga IV: Ayah Karyawan Swasta, Ibu Dosen}

Motivasi dual-career: Memanfaatkan ilmu yang telah diperoleh

Pihak kedua: Pengasuh anak 
Model pemenuhan asih: Mencurahkan waktu anak untuk bersama saat tidak bekerja, seperti mengajak bermain, sholat bersama, membaca al-qur'an. Serta mendekatkan anak dengan keluarga, mengenalkan anak dengan orang-orang yang ada lingkungan sekitar, dan lain-lain.

\section{Keluarga V: Ayah Guru, Ibu Dosen}

Motivasi dual-career: Mengamalkan ilmu yang telah diperoleh dan eksistensi diri.

Pihak kedua: Pengasuh anak

Pemahaman tentang golden age: Masa dimana anak butuh pendampingan dan perhatian yang lebih karena proses tumbuh kembang anak pada masa emas.

Model pemenuhan asih: Memberikan kualitas kebersamaan yang baik pada saat dirumah dan hari libur.

\section{Keluarga VI: Ayah Karyawan Swasta, Ibu Dosen}

Motivasi dual-career: Untuk memenuhi kebutuhan sehari-hari keluarga.

Pihak kedua: Bibi

Pemahaman tentang golden age: Usia perkembangan anak yang paling baik dari segi bahasa, emosi, sosial, fisik dan tindakan.

Model pemenuhan asih: Menghabiskan waktu bersama-sama pada saat dirumah dan waktu libur kerja.

Dari data di atas, diketahui bahwa hampir semua orang tua memiliki pengetahuan tentang pentingnya perkembangan anak di masa golden age akan tetapi masih terdapat orang tua yang kurang memiliki kesadaran bahwa yang berperan penting dalam perkembangan tersebut adalah dampingan dari orang tua langsung.

Setiap keputusan mempunyai konsekuensi bagi orangtua saat memutuskan pilihan dual-career karena setiap anggota keluarga berperan sebagai partisipan dalam 
berbagai subsistem baik yang bersifat dyadic (melibatkan dua orang) maupun polyadic (melibatkan lebih dari dua orang). Subsistem-subsistem di atas saling berinteraksi dan saling mempengaruhi terutama pada pola pengasuhan dalam pemeberian perhatian secara khusus dan hati-hati terhadap pemenuhan kebutuhan dasar anak, atau sekedarnya dan tidak perlu menjadi prioritas. Hal ini terlihat dari bagiaman cara keluarga memandang dan menilai kompetensi pengasuh yang dilimpahkan tanggungjawab pengasuhan selama orangtua bekerja. dari hasil pengamatan yang dilakukan peneliti masih terdapat keluarga yang belum memberikan perhatian khusus dalam menyikapi hal tersebut, akan tetapi terdapat keluarga yang menyadari bahwa status dual-career harsulah diikuti dengan usaha memebuhi kebutuhan dasar anak dalam melalui tahap-tahap perkembangan anak. Perbedaan sikap masing-masing subyek penelitian rupanya dipengaruhi oleh pengalaman, pengetahuan dan status sosial ekonomi keluarga.

\section{Pembahasan}

Keluarga merupakan suatu sistem yang kompleks dimana didalamnya terdapat ikatan diantra anggota keluarganya dan saling memiliki. Di lingkungan keluarga inilah terjadi proses pengasuhan demi terbentuknya pribadi yang matang untuk dapat menjalani kehidupan sesuai yang diharapkan. Salah satu sosok yang paling berperan dalam pembentukan kepribadian tersebut tentunya adalah orang tua. Orang tua menjadi pendamping utama dalam setiap perkembangan anak. Orang tua menjadi contoh pertama dan yang paling utama bagi anak. Orang tua melakukan "investasi dan komitmen dalam kehidupan anak" untuk memberikan tanggung jawab dan perhatian.

Struktur keluarga menggambarkan peran masing-masing anggota keluarga baik didalam keluarganya sendiri maupun perannya dilingkungan masyarakat. Semua 
tindakan dan perilaku yang dilakukan oleh anggota keluarga menggambarkan nilai dan norma yang dipelajari dan diyakini.

Dalam penelitiannya yang berjudul "Proses Pengasuhan Ibu Bekerja", menemukan bahwa kualitas pengasuhan sebuah pasangan orangtua dapat dilihts pengasuhan yang diberikan kepada anak-anaknya. Proses pengasuhan yang dimaksud antara lain adalah sebagai berikut (Suyunus, 2012: 9):

a. Perencanaan Pengasuhan. Perencanaan pengasuhan ibu bekerja dimulai sejak anak dalam kandungan. Dalam tahap ini dilakukan berbagai ritual tertentu dengan harapan anak akan lahir sehat dan menjadi anak yang diharapkan. Bahkan informan percaya bahwa ritual tertentu berpengaruh terhadap kepribadian anak kelak. Persiapan dalam menyambut kelahiran juga tidak terlepas dari pengalaman yang didapatkan dari orang tua terdahulu.

b. Kegiatan Pengasuhan. Kegiatan pengasuhan yang dilakukan selalu berkaitan dengan sosok seorang ibu yang dalam penelitian ini memiliki peran yang dominan dalam tahap perkembangan anak. Dalam prosesnya, ketiga informan melibatkan pengasuhan dalam setiap aktivitas kerja. Hal ini tidak terlepas dari harapan tinggi terhadap anak untuk bisa menjadi lebih dari orang tua. Meskipun profesi yang dimiliki informan sedikit banyak membantu keuangan keluarga namun ketiga informan tetap berfokus pada pengasuhan.

c. Keterlibatan Ibu dalam Pengasuhan. Ibu menjadi figur penting bagi anak, dalam penelitian ini dapat dilihat ketika ibu dapat melahirkan anak yang sehat, normal dan sesuai dengan harapan informan. kedekatan antara ibu dan anak sangat jelas terlihat dimana anak memilih untuk tetap bersama ibu meskipun di-dua-kan oleh aktivitas pekerjaann. Meskipun ibu tidak sepenuhnya dapat memenuhi 
kebersamaan dengan anak namun sosok ibu dapat memberikan perhatian lebih dalam setiap tahap perkembangan anak. Hasil penelitian menunjukkan bahwa ketiga informan dapat memberikan rasa aman dan kasih sayang terhadap anak. Sejalan dengan hal tersebut, informan memiliki harapan dan tindakan yang sesuai untuk mendidik anak hingga mereka dapat mencapai cita-cita yang diinginkan.

d. Proses Membagi Waktu Pengasuhan dan Pekerjaan. Proses membagi waktu dilakukan dengan berbagai cara sesuai dengan pengalaman yang informan dapatkan tentang pengasuhan. Dalam hal ini masing-masing informan memiliki keunikan tersendiri. Bahkan salah satu informan lebih nyaman untuk membawa anak dalam lingkungan kerja. Hal ini tidak lain dikarenakan rasa nyaman anak bersama ibu sehingga anak memilih untuk tetap bersama ibu dengan beragam aktivitas pekerjaannya. Selain itu, mereka membuat kesepakatan dengan suami untuk saling berbagi tugas tanpa mengabaikan pekerjaan. Sehingga meskipun disibukkan dengan pekerjaan tetap tidak mengabaikan aktivitas pengasuhan yang menjadi prioritas utama.

Dr. K. Uthayasutiyan dan S. Gunapalan dalam simpulan penelitian mereka yang berjudul "Dual Career Family Life Style" mengungkapkan bahwa: "Family-work balance is a process, not a static achievement. It is important to make the big decision selecting careers and jobs, timing children, allocating roles and responsibilities, etc. that will provide the opportunity for balance”. Keseimbangan tugas pengasuhan pada keluarga dual-career adalah sebuah proses dan bukan sebuah pencapaian statis. Keputusan besar yang diambil keluarga dual-career berkenaan dengan status pekerjaan mereka, kemampuan membagi waktu, merawat anak-anak, serta mengatur waktu secara bijak untuk peran dan tanggungjawabnya di rumah maupun di tempat 
kerja, adalah sesuatu yang terus-menerus melalui tahapan-tahapan belajar menuju keseimbangan. Pada akhirnya, anak-anak tumbuh diasuh oleh sang waktu. Waktu yang oleh orangtua mereka entah akan diisi dengan cinta kasih, ataukah waktu yang oleh orangtua mereka dilalui dengan tanpa meninggalkan jejak yang tak terlalu berarti dalam proses tumbuh-kembang anak-anaknya sepanjang hayat.

\section{PENUTUP}

Berdasarkan permasalahan yang terdapat pada latarbelakang tersebut peneliti mencoba mencari pemecahan dengan menggali data secara mendalam bagaimana mencukupi kebutuhan Asih anak dimana kedua orang tua sama-sama bekerja, penelitian ini juga memberikan kontribusi bagaimana mencukupi kebutuhan anak khususnya kebutuhan Asih.

\section{REFERENSI}

Adiwibowo, Suyunus. Kepemimpinan dan Loyalitas Terhadap Kinerja Karyawan RSJ Menur Surabaya. Jurnal Manajemen Bisnis, Vol 2, No. 01, Edisi April 2012

Arikunto, Suharsimi. 2010. Prosedur Penelitian Suatu pendekatan Praktek. Jakarta: Rineka Cipta.

Asfriyati. 2003. Pengaruh Keluarga Terhadap Kenakalan Anak. Universitas Sumatera Utara. Medan.

Brooks., et al, 2008. Mikrobiologi Kedokteran. Ed. 23. Jakarta : EGC.

Gunarsa \& Gunarsa. 2000. Psikologi Praktis : Anak Remaja dan Keluarga. PT. BPK Gunung Mulia: Jakarta

Hurlock B.E, 2007. Psikologi Perkembangan Suatu Pendekatan Sepanjang Rentang Kehidupan. Penerbit Erlangga. Jakarta.

Hertz, M.F. \& David, F.C. 2008. Electronic Media and Youth Violence: A CDC Issue Brief for Educators and Caregivers. Atlanta (GA): Centers for Disease Control.

Nawawi, Hadari. 2003. Manajemen Sumber Daya Manusia Untuk Bisnis yang Komptitif, Gadjah Mada University Press, Yogyakarta.

Santrock, J.W. 2002. Life-Span Development: Perkembangan Masa Hidup (edisi kelima). (Penerj. Achmad Chusairi, Juda Damanik; Ed. Herman Sinaga, Yati Sumiharti). Jakarta: Erlangga

Sujiono, Y.N. (2009). Konsep Dasar Pendidikan Anak Usia Dini. Indeks. Jakarta.

Uthayasutiyan, K., dkk. (2011). Dual Career Family Life Style. http://www.seu.ac.lk/researchandpublications/fmc\%20journal/Journal\%20of\%20 Managment\%202/Dual\%20Career\%20Family.pdf 
JCE (Journal of Childhood Education) VOL(3), NO(1), Edisi Maret 2019

2620-3278 (E-ISSN), 2598-2184 (P-ISSN)

Hal: 01-17 